\title{
장 \\ U.S. GEOLOGICAL SURVEY GROUND-WATER STUDIES IN MISSOURI
}

\section{GROUND-WATER ISSUES}

Ground-water sources supply the water needs of about 40 percent of Missouri's population; except in the St. Louis and Kansas City areas, ground water is a significant source for many public supplies. Ground water is the source of all rural domestic self-supplied water, 93 percent of all irrigation water, and 42 percent of all industrial self-supplied water (excluding water for thermoelectric power generation). The major issues related to ground water in Missouri are:

- Effects of land use on ground-water quality.

- Contamination of ground water by hazardous wastes, and

- Decreasing ground-water supplies.

\section{U.S. GEOLOGICAL SURVEY PROGRAMS}

The U.S. Geological Survey (USGS), established in 1879 , is the principal source of scientific and technical expertise in the earth sciences within the Federal government. USGS activities include research and services in the disciplines of geology, hydrology, and cartography. The mission of the Water Resources Division of the USGS is to develop and disseminate scientific information on the Nation's water resources. The activities of the Water Resources Division in Missouri are conducted by scientists, technicians, and support staff in offices in Rolla, Olivette, and Independence.

Hydrologic-data stations are maintained at selected locations throughout Missouri and constitute a water-resources network to record data on stream discharge and stage, reservoir and lake storage, ground-water levels, well and spring discharge, and the quality of surface and ground water. Water-resources data are stored in the USGS National Water Data Storage and Retrieval System data base. These data are used by water planners and others involved in decisions that affect the water resources of Missouri.

During 1987, the USGS, in cooperation with Federal, State, and local agencies, maintained a network of about 250 wells in Missouri to monitor fluctuations in water levels. Water-level measurements from wells are used to monitor ground-water trends; however, they need to be integrated with other observations and ground-water investigations to be most relevant and useful.

The USGS has conducted about 75 hydrologic investigations in Missouri. During fiscal year 1987, the USGS had cooperative or cost-sharing agreements with 20 Federal, State, and local agencies involving 20 hydrologic investigations in Missouri;
13 investigations included studies of ground-water quantity and quality. These investigations provide information to answer questions that are specific to the State's principal ground-water issues. Also, some of these investigations provide information on statewide, multistate, and national hydrologic issues. Three examples of ground-water studies by the USGS that address specific ground-water issues in Missouri are discussed in the following sections.

\section{Occurrence of Pesticides, Southeastern Missouri}

The Mississippi alluvial plain in southeastern Missouri is intensively used for agriculture. An estimated 609,000 pounds and 671,000 gallons of pesticides were used on more than 2.3 million acres in 1984. Increased and prolonged use of pesticides is a potential threat to the ground-water resources in the area. Information on the occurrence and quantity of common pesticides in ground water was needed to determine the magnitude and extent of pesticide contamination. From 1986 through 1987, the USGS, in cooperation with Missouri Department of Health, collected water samples from domestic, irrigation, and public-supply wells to study the occurrence of

STUDY AREAS

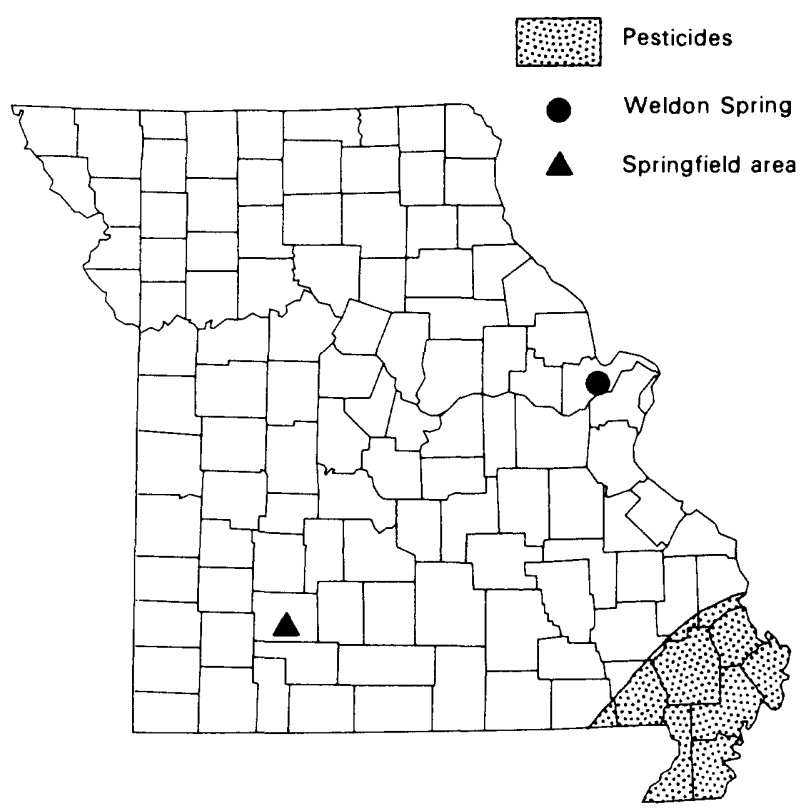


pesticides. The results of the study indicate that pesticides are present in the ground water. None of the pesticides detected in domestic or public-supply wells exceeded health-advisory or maximum-contaminant levels set by the U.S. Environmental Protection Agency for the few pesticides for which water-quality criteria have been established.

\section{Radioactive Contamination at Weldon Spring}

The Atomic Energy Commission processed uranium and thorium at a plant near Weldon Spring in St. Charles County from 1957 to 1966 . Residues from the operation were disposed of in four pits near the plant. Radioactive wastes from other areas and some wastes from the Weldon Spring plant also were disposed of in an abandoned limestone quarry several miles away. Both waste-disposal sites are under the jurisdiction of the U.S. Department of Energy (DOE). The USGS, in cooperation with the DOE, compiled hydrologic data and drilled test wells to obtain additional data on ground-water conditions at Weldon Spring. Chemical analyses indicate that water in the shallow bedrock aquifer contains large concentrations of calcium, lithium, magnesium, nitrate, sodium, strontium, sulfate, and uranium near the four pits. A spring 1.5 miles north of the site also has increased lithium, nitrate, and uranium concentrations. Further activities by the USGS include monitoring ground-water levels and quality, and the development of ground-water flow and solute-transport models. These models will help water managers to determine the magnitude and extent of radioactive contamination at the site.

\section{Ground-Water in the Springfield Area}

Large quantities of ground water are pumped by the city of Springfield and by local private industry. As a result, more new water-supply wells may be needed to meet the demands of increasing population and industrial use. Most wells are open to the deeper of two aquifers that underlie the Springfield area. Contaminants may be able to move downward from the upper limestone aquifer, through rocks separating the two aquifers, into the deep aquifer. The USGS, in cooperation with city utilities of Springfield, is developing a ground-water-flow model of the aquifer system. The model will be used by the city utilities of Springfield to estimate the present rate and potential effects of vertical leakage between the two aquifers under assumed future pumping rates, to determine the effects of ground-water withdrawals in the deep aquifer on ground-water levels in the overlying aquifer, and to assess the potential for contamination of the deep aquifer by leakage through the confining unit.

\section{GROUND-WATER MANAGEMENT}

The principal State agencies responsible for ground-water management in Missouri are the Department of Natural Resources' Division of Geology and Land Survey (DGLS) and Division of Environmental Quality (DEQ), and the Missouri Division of Health (MDH). The DGLS is responsible for the administration of water law in Missouri. The DEQ supervises the design and construction of water-supply systems and, in cooperation with the $\mathrm{MDH}$, monitors contaminants in water supplies. All of these agencies use ground-water data and the results of ground-water studies provided by the USGS. During 1987-88, the following Federal, State, and local agencies entered into interagency or cooperative cost-sharing agreements with the USGS to conduct ground-water investigations in Missouri:

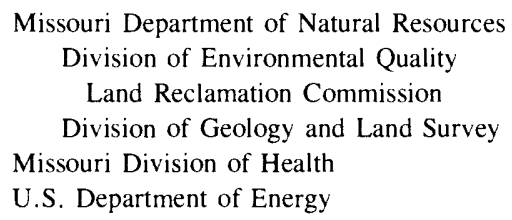

\section{SELECTED REFERENCES}

Kleeschultee, J.J., and Emmett, L.F., 1987, Hydrology and water quality at the Weldon Spring radioactive waste-disposal sites, St. Charles County, Missouri: U.S. Geological Survey Water-Resources Investigations Report 87-4169, 65 p.

Smith, B.J., and Jenkins, K.L., compilers, 1988, Water resources activities of the U.S. Geological Survey in Missouri, fiscal year 1987: U.S. Geological Survey Open-File Report 88-99, 66 p.

U.S. Geological Survey, 1984, National water summary 1983Hydrologic events and issues: U.S. Geological Survey Water-Supply Paper 2250, $243 \mathrm{p}$.

1985, National water summary 1984-Hydrologic events, selected water-quality trends, and ground water resources: U.S. Geological Survey Water-Supply Paper 2275, 467 p.

Information on technical reports and data related to ground water in Missouri can be obtained from:

District Chief
U.S. Geological Survey
Water Resources Division
1400 Independence, Mail Stop 200
Rolla, Missouri 65401
Director
Missouri Water Resources Research Center
Sinclair Road. Route 3
Columbia, Missouri 65201

District Chief

U.S. Geological Survey

1400 Independence, Mail Stop 200

Rolla, Missouri 65401

Missouri Water Resources Research Center

Columbia, Missouri 65201 